Situs Jurnal : http://ejournal.stiepancasetia.ac.id/index.php/jieb

Jilid 6 Nomor 3 November 2020

Hal 386 - 400

\title{
PENGARUH KINERJA KEUANGAN TERHADAP HARGA SAHAM PERUSAHAAN (STUDI KASUS PADA PERUSAHAAN JASA TRANPORTASI YANG TERDAFTAR DI BEI PERIODE 2015-2019)
}

\section{Dhani Aspriyadi}

Abstrak: Penelitian ini bertujuan untuk mengetahui dan menganalisis pengaruh Current Ratio, Debt to Equity Ratio, Return On Assets, Return On Equity, dan Earning Per Share secara simultan, parsial dan dominan terhadap harga saham. Pada penulisan skripsi ini, metode penelitian yang digunakan oleh peneliti adalah metode penelitian korelasional. Korelasional dari kata dasarnya korelasi. Populasi dalam penelitian ini yang menjadi objek penelitian adalah perusahaan yang bergerak di sektor jasa transportasi yang terdaftar di Bursa Efek Indonesia (BEI) pada periode 2015-2019. Dengan jumlah populasi sebanyak 43 perusahaan. Pemilihan sampel menggunakan metode purposive sampling, diperoleh perusahaan yang memenuhi kriteria sebanyak 9 perusahaan. Hasil penelitian pada penelitian ini menunjukan Current Ratio, Debt to Equity Ratio, Return On Assets, Return On Equity, dan Earning Per Share berpengaruh secara simultan terhadap harga saham Perusahaan Jasa Tranportasi yang Terdaftar di BEI Periode 2015-2019. Current Ratio dan DER (Debt to Equity Ratio) tidak berpengaruh signifikan terhadap Harga Saham Pada Perusahaan Jasa Tranportasi yang Terdaftar di BEI Periode 20152019. ROA (Return On Assets), ROE (Return On Equity) dan Earning Per Share (EPS) berpengaruh signifikan terhadap Harga Saham Pada Perusahaan Jasa Tranportasi yang Terdaftar di BEI Periode 2015-2019. Earning Per Share (EPS) berpengaruh signifikan terhadap Harga Saham Pada Perusahaan Jasa Tranportasi yang Terdaftar di BEI Periode 2015-2019

Kata Kunci : Current Ratio, Debt To Equity Ratio, Return On Assets, Return On Equity, Dan Earning Per Share, Harga Saham 


\section{Latar Belakang}

Dari data Mirae Asset Sekuritas yang dikutip Suara.com sudah terjadi sejumlah penurunan harga saham yang cukup dalam dari Januari hingga Maret 2020. Pertama, harga saham PT Jasa Marga (Persero) Tbk (JSMR) yang merosot sebesar 45 persen dari harga Rp 4.900 menjadi Rp 2.690 per lembar saham. Kedua, harga saham PT Garuda Indonesia (Persero) Tbk (GIAA) yang jatuh 65 persen dari harga Rp 500 menjadi Rp 159 per lembar saham. Terakhir ketiga, harga saham PT Indonesia Kendaraan Terminal Tbk (IPCC) yang tak bisa akselerasi dan jatuh sebesar 68 persen dari harga Rp 700 menjadi Rp 245 per lembar saham. Suara.com (2020).

Peraturan terkait dengan saham yang beredar, regulator pasar modal tegas mengatur jumlah saham minimal beredar di publik (free float). Payung hukumnya terutama Peraturan Bursa Efek Indonesia (BEI) nomor IA tentang Pencatatan Saham dan Efek Bersifat Ekuitas Selain Saham yang Diterbitkan Oleh Perusahaan Tercatat. Dalam aturan tersebut, free float setiap emiten alias perusahaan yang listing di bursa harus minimal 7,5 persen (dari total saham disetor dan dicatatkan) dan minimal 50 juta saham serta dimiliki minimal 300 pihak di luar dari pihak pengendali dan pemilik perusahaan.

Harga saham adalah salah satu tolak ukur kinerja suatu perusahaan. "Harga saham dilantai bursa ditentukan oleh kekuatan pasar, yang di indikasikan bahwa harga saham tergantung dari kekuatan permintaan dan penawaran" Menurut Harianto dan Sudomo (1998) dalam Tyastari (2015). Harga saham dapat disimpulkan sebagai harga di bursa saham pada saat tertentu yang ditentukan oleh pelaku pasar, permintaan dan penawaran saham yang bersangkutan di pasar modal.

Harga saham merupakan tanda penyertaan atau kepemilikan seseorang atau badan dalam suatu perusahaan. Harga saham ini dapat juga diartikan sebagai harga jual beli yang berlaku di pasar efek yang ditentukan oleh kekuatan pasar. Semakin tinggi nilai dari harga saham, maka investor akan tertarik untuk menjual sahamnya.

Berdasarkan nilai harga saham mayoritas perusahaan jasa transportasi yang masuk dalam kriteria penelitian ini adalah cenderung menurun. Hal ini dapat diartikan slama periode penelitian, aktivitas atau transaksi yang dominan terjadi adalah investor menjual sahamnya, namun di sisi lain dengan semakin menurunnya harga saham tersebut ada kemungkinan investor tertarik untuk membeli saham-saham tersebut

Para investor sebelum bertransaksi dalam pasar saham, terlebih dahulu melihat laporan keuangan perusahaan untuk mengetahui kondisi keuangan perusahaan pada periode tertentu. Aktivitas pelaporan keuangan dituangkan dalam bentuk angka angka, baik dalam mata uang rupiah atau dalam bentuk mata uang asing. Angka angka dalam laporan keuangan tersebut dibandingkan dengan laporan keuangan periode tertentu. Kegiatan membandingkan laporan keuangan tersebut disebut dengan analisis rasio keuangan. Menurut Horne dalam Kasmir (2012) rasio keuangan adalah indeks yang menghubungkan dua angka akuntansi dan diperoleh dengan membagi satu angka dengan angka lainnya. Hasil dari analisis rasio keuangan tersebut digunakan untuk menilai kinerja keuangan manajemen dalam suatu periode tertentu, dan dapat menilai kemampuan manajemen dalam membesarkan sumber daya perusahaan secara efektif.

Rasio - rasio yang digunakan untuk menilai kinerja keuangan perusahaan dalam penelitian ini terdiri dari current ratio, debt to equity ratio, return on assets dan return on equity. Rasio - rasio tersebut dipilih berdasarkan dari saran dan hasil penelitian sebelumnya, karena menunjukan beberapa hasil yang berbeda. Current ratio adalah rasio yang mengukur kemampuan perusahaan dalam memenuhi kewajiban jangka pendek (Bringham \& Huston, 2010). 
Rasio lancar merupakan rasio yang paling umum digunakan untuk mengukur likuiditas perusahaan atau kemampuan perusahaan untuk memenuhi kewajiban jangka pendek tanpa menghadapi kesulitan. Semakin tinggi rasio berarti semakin terjamin hutang-hutang perusahaan kepada kreditur. Untuk prinsip kehati-hatian, besaran current ratio yang baik sekitar 200 persen.

Berdasarkan nilai rasio lancar (current ratio) mayoritas perusahaan jasa transportasi yang masuk dalam kriteria penelitian ini adalah berada di bawah angka 200 persen. Artinya mayoritas perusahaan tersebut, perlu waspada atau bahkan cukup kesulitan jika harus memenuhi kewajiban jangka pendek tanpa. Hanya PT Pelayaran Nelly Dwi Putri Tbk, PT Mitra Bantera Segara Sejati Tbk dan PT Cardig Aero Services Tbk dengan nilai rasio lancar (current ratio) yang cukup tinggi. Artinya ketiga perusahaan tersebut memiliki kemampuan yang tinggi untuk memenuhi kewajiban jangka pendek tanpa menghadapi kesulitan

Selanjutanya, debt to equity ratio adalah rasio yang menilai utang dan ekuitas perusahaan (Kasmir, 2012). Secara umum, rasio ini berguna untuk mengetahui setiap rupiah modal sendiri yang dijadikan untuk jaminan utang. Jika nilai rasio ini semakin tinggi maka akan semakin tidak menguntungkan bagi kreditur, dikarenakan akan semakain besar risiko yang ditanggung atas kegagalan yang dapat dialami perusahaan.

Berdasarkan nilai Debt on Equity Ratio mayoritas perusahaan jasa transportasi yang masuk dalam kriteria penelitian ini adalah cukup rendah. Artinya risiko yang ditanggung atas kegagalan yang mungkin dialami perusahaan adalah kecil. Hanya PT Humpuss Intermoda Transportasi Tbk, PT Garuda Indonesia (Persero) Tbk dan PT Adi Sarana Armada Tbk dengan nilai Debt on Equity Ratio yang cukup tinggi. Artinya kondisi tersebut tidak menguntungkan bagi kreditur, dikarenakan akan semakain besar risiko yang ditanggung atas kegagalan yang dapat dialami perusahaan

Kemudian, return on assets adalah rasio yang mengukur tingat pengembalian aktiva perusahaan (Bringham \& Huston, 2012). Terakhir, return on equity adalah rasio yang digunakan untuk melihat tingkat efesiensi perusahaan dalam mengelola ekuitasnya untuk menghasilkan laba bersih perusahaan (Ikhsan, Alfurkaniati, Safrida, Lubis, Dalimunthe \& Abdullah, 2012). Rasio ini mampu menunjukan keberhasilan perusahaan dalam menghasilkan keuntungan. ROA mampu mengukur keberhasilan perusahaan menghasilkan keuntungan di masa lampau kemudian diproyeksikan pada masa yang akan datang. Semakin tinggi nilai ROA tersebut, maka semakin baik pula kemampuan perusahaan mengelola asetnya.

Berdasarkan nilai Return on Asset mayoritas perusahaan jasa transportasi yang masuk dalam kriteria penelitian ini adalah cukup rendah yang berada pada sekitaran angka dibawah 10 persenan. Hal ini dapat diartikan mayoritas perusahaan tersebut kurang baik dalam mengelola asetnya.

Selain Return on Asset yang mempengaruhi harga saham adalah ROE. Pengembalian ekuitas biasa (ROE) merupakan rasio yang membagi laba setelah pajak dengan rata - rata modal pada sebuah perusahaan. Rasio ini digunakan untuk melihat tingkat efesiensi perusahaan dalam mengelola ekuitasnya untuk menghasilkan laba bersih perusahaan" (Ikhsan, Alfurkaniati, Safrida, Lubis, Dalimunthe, \& Abdulah, 2016 : 82). Rasio ini digunakan untuk melihat tingkat efesiensi perusahaan dalam mengelola ekuitasnya untuk menghasilkan laba bersih perusahaan. Semakin tinggi return atau penghasilan yang diperoleh maka semakin baik kedudukan atau posisi pemilik perusahaan.

Berdasarkan nilai Return on Equity mayoritas perusahaan jasa transportasi yang masuk dalam kriteria penelitian ini adalah 
cukup rendah yang berada pada sekitaran angka negatif. Hal ini dapat diartikan kedudukan atau posisi pemilik perusahaan pada mayoritas perusahaan tersebut kurang baik.

Selain Return on Equity faktor yang mempengaruhi harga saham adalah Earning Per Share (EPS). Earning Per Share (EPS) merupakan salah satu komponen yang diperhatikan dalam analisis perusahaan. Informasi EPS suatu perusahaan menunjukkan besarnya laba bersih perusahaan yang siap dibagikan untuk semua pemegang saham perusahaan. EPS merupakan rasio yang menunjukkan berapa besar keuntungan (return) yang diperoleh investor atau pemegang saham per lembar saham. Pada umumnya manajemen perusahaan, pemegang saham biasa dan calon pemegang saham sangat tertarik pada Earning Per Share (EPS), karena hal ini menggambarkan jumlah rupiah yang diperoleh untuk setiap lembar saham biasa dan menggambarkan prospek earning perusahaan di masa depan. (Gede Priana Dwipratama. 2009).

Earning per Share bisa disebut juga sebagai pendapatan bersih per lembar saham, yaitu jumlah pendapatan yang didapat dari tiap-tiap lembar saham biasa yang disetorkan perusahaan. Prinsip umumnya adalah semakin tinggi nilai EPS perusahaan, maka semakin menguntungkan untuk berinvestasi didalamnya.

Berdasarkan nilai Earning per Share mayoritas perusahaan jasa transportasi yang masuk dalam kriteria penelitian ini adalah cukup rendah yang berada pada sekitaran angka negatif. Hal ini dapat diartikan bahwa relatif kurang menguntungkan jika ingin berinvestasi didalam perusahaan-perusahaan tersebut. Hanya PT Samudera Indonesia Tbk, PT Blue Bird Tbk dan PT Pelayaran Tempuran Emas Tbk dengan nilai Earning per Share cukup tinggi. Artinya para investor secara relative berpeluang besar meraih keuntungan jika berinvestasi didalam perusahaan tersebut
Sektor transportasi merupakan kebutuhan yang penting sebagai mobilisasi terhadap kegiatan perekonomian. Karena melalui sektor tranportasi merupakan gerbang untuk memperluas jaringan bisnis, terutama yang memiliki potensi sehingga dapat dikembangkan ke taraf internasional. Perusahaan jasa transportasi juga harus menunjukan kinerja keuangan yang baik untuk dapat menarik para investor sebagai tambahan modal untuk keberlangsungan hidup perusahaan.

Penelitian yang dilakukan Lestari (2019) menunjukan bahwa secara parsial Return On Assets (ROA) dan Return On Equity (ROE) berpengaruh positif dan signifikan terhadap harga saham. Sedangkan Debt to Equity Ratio (DER), Current Ratio (CR), dan Net Profit Margin (NPM) tidak berpengaruh positif terhadap harga saham. Selanjutnya dalam penelitian Zuliarni (2012) yang meneliti pengaruh kinerja keuangan terhadap harga saham pada perusahaan Mining and Mining Service di BEI dengan variabel Return On Assets (ROA), Price Earning Ratio (PER), dan Dividend Payout Ratio (DPR). Hasil dari dari penelitian tersebut yang menggunakan analisis regresi linier berganda (Uji t dan $\mathrm{f}$ ) menunjukan hasil yang berbeda, hasil pengujian secara parsial (uji t) hanya dua yang berpengaruh yaitu variabel Return On Assets (ROA) dan Price Earning Ratio (PER). Sedangkan pengujian parsial (uji f) secara simultan menunjukan bahwa ROA, PER dan DPR beprengaruh positif secara bersamaan terhadap harga saham.

Hasil penelitian yang berbeda ditunjukan oleh Tyastari (2015) yang menggunakan variabel independen Laba Operasi, Tingkat Pengembalian Aset (ROA), Tingkat Pengembalian Ekuitas (ROE), dan Laba Per Saham (EPS). Hasil penelitian menunjukan bahwa Laba Operasi dan Laba Per Saham memiliki pengaruh positif terhadap harga saham, sedangkan variabel ROA dan ROE berpengaruh negatif terhadap harga saham.

JIEB, Jilid 6, No 3, November 2020 ISSN Online 2615-2134 
Karena terdapat perbedaan dari beberapa hasil penelitian, maka peneliti ingin melakukan penelitan mengenai pengaruh kinerja keuangan terhadap harga saham. Penelitian ini merupakan replikasi dari penelitian Lestari (2019) yang menggunakan variabel (ROA, ROE, DER, CR dan NPM) untuk kinerja keuangan yang akan diuji untuk menganalisis pengaruhnya terhadap harga saham. Sedangkan alat ukur kineja keuangan yang digunakan peneliti dalam penelitian ini adalah current ratio (CR), debt to equity ratio (DER), return on equity (ROE) dan return on assets (ROA). Alat ukur kinerja keuangan yang dipilih berdasarkan dari variabel - variabel penelitian terdahulu.

Dengan banyaknya kegiatan dalam sektor jasa transportasi memberikan dampak pada fluktuasi harga saham. Berdasarkan data diatas diketahui sektor transportasi mengalami pertumbuhan harga saham yang signifikan pada tahun 2018 .

Pemilihan perusahaan jasa transportasi di BEI dikarenakan jasa transportasi merupakan sektor yang sangat terkait dengan perkembangan dan pembangunan perekonomian dunia dan negara. Tahun-tahun sebelumnya kondisi perekonomian di Indonesia mengalami keterpurukan akibat krisis moneter. Pada tahun 2008 terjadi krisis global, sehingga pertumbuhan laba perusahaan jasa transportasi banyak mengalami penurunan.

Kinerja emiten transportasi sepanjang kuartal III 2019 cukup bervariatif. Sejumlah emiten mencatatkan pertumbuhan pendapatan, serta beberapa perusahaan masih dibebani rugi bersih. PT Adi Sarana Armada Tbk (ASSA), PT Weha Transportasi Indonesia Tbk (WEHA) berhasil menorehkan pertumbuhan pendapatan meski laba bersih menurun. Sementara pendapatan PT Blue Bird Tbk (BIRD), dan PT Express Trasindo Utama Tbk (TAXI) tercatat turun.

Berdasarkan uraian yang telah disampaikan, kinerja keuangan perusahaan sangat penting untuk keberlangsungan perusahaan. Kinerja keuangan perusahaan dapat dinilai melalui analisis rasio atas laporan keuangan sehingga dapat mempengaruhi harga nilai saham perusahaan terhadap para investor. Terkait dengan permaslahan di atas, peneliti tertarik untuk melakukan penelitian dengan judul : "Pengaruh Kinerja Keuangan Terhadap Harga Saham Perusahaan (Studi Kasus pada Perusahaan Jasa Tranportasi yang Terdaftar di BEI Periode 2015-2019)".

\section{Rumusan Masalah}

1. Apakah Current Ratio, Debt to Equity Ratio, Return On Assets, Return On Equity dan Earning Per Share berpengaruh secara simultan terhadap harga saham?

2. Apakah Current Ratio, Debt to Equity Ratio, Return On Assets, Return On Equity dan Earning Per Share berpengaruh secara parsial terhadap harga saham?

3. Variabel manakah yang berpengaruh dominan terhadap harga saham ?

\section{Tujuan Penelitian}

1. Untuk mengetahui dan menganalisis pengaruh Current Ratio, Debt to Equity Ratio, Return On Assets, Return On Equity, dan Earning Per Share secara simultan terhadap harga saham.

2. Untuk mengetahui dan menganalisis pengaruh Current Ratio, Debt to Equity Ratio, Return On Assets, Return On Equity dan Earning Per Share secara parsial terhadap harga saham.

3. Untuk mengetahui variabel yang berpengaruh dominan terhadap harga saham

\section{Kajian Pustaka}

1. Harga Saham (Y)

Harga saham menurut Susanto (2016:12), yaitu harga yang ditentukan secara lelang kontinu. Sedangkan, menurut Sartono (2016:70) harga pasar saham terbentuk melalui mekanisme permintaan dan penawaran di pasar modal. Sebagai variabel terikatnya (Y), yang digunakan yaitu harga saham 
penutupan/closing price karena harga tersebut mengalami kenaikan dan penurunan secara wajar

2. Current Ratio $\left(\mathrm{X}_{1}\right)$

Rasio lancar merupakan adalah rasio yang mengukur kemampuan perusahaan dalam memenuhi kewajiban jangka pendek (Bringham dan Houston, 2015). Rasio lancar merupakan rasio yang paling umum digunakan untuk mengukur likuiditas perusahaan atau kemampuan perusahaan untuk memenuhi kewajiban jangka pendek tanpa menghadapi kesulitan.Rasio lancar ini dihitung dengan rumus sebagai berikut

$$
\text { Rasio Lancar }=\frac{\text { Total Aktiva Lancar }}{\text { Total Utang Lancar }} \times
$$

\section{1 kali}

(Ikhsan, Alfurkaniati, Safrida, Lubis, Dalimunthe, \& Abdulah, 2016).

3. Debt to Equity Ratio $\left(\mathrm{X}_{2}\right)$

Rasio utang pada ekuitas (debt to equity ratio) merupakan rasio yang digunakan untuk menilai utang dengan ekuitas. (Kasmir, 2016 : 157). Secara umum, rasio ini berguna untuk mengetahui setiap rupiah modal sendiri yang dijadikan untuk jaminan utang. Jika nilai rasio ini semakin tinggi maka akan semakin tidak menguntungkan bagi kreditur, dikarenakan akan semakain besar risiko yang ditanggung atas kegagalan yang dapat dialami perusahaan. Rumus untuk mencari rasio utang terhadap modal dapat digunakan sebagai berikut :

Rasio Utang pada Ekuitas (DER) $=$ $\frac{\text { Total Utang }}{\text { Modal Sendiri }} \times 100 \%$

(Kasmir, 2016

4. Return On Assets $\left(\mathrm{X}_{3}\right)$

Menurut Bringham dan Houston (2016) pengembalian atas total aktiva (ROA) dapat dihitung dengan cara membandingkan laba bersih yang tersedia untuk pemegang saham biasa dengan total aktiva. Pengembalian atas total aset (Return on Aset) merupakan salah satu rasio profitabilitas. Rasio ini mampu menunjukan keberhasilan perusahaan dalam menghasilkan keuntungan. ROA mampu mengukur keberhasilan perusahaan menghasilkan keuntungan di masa lampau kemudian diproyeksikan pada masa yang akan datang. Rasio ROA dapat dihitung dengan rumus sebagai berikut :

Pengembalian atas Total Aset $(\mathrm{ROA})=$ $\frac{\text { Laba Bersih }}{\text { Total Aset }} \times 100 \%$

(Ikhsan, Alfurkaniati, Safrida, Lubis, Dalimunthe, \& Abdulah, 2016)

5. Return On Equity $\left(\mathrm{X}_{4}\right)$

Pengembalian ekuitas biasa (ROE) merupakan rasio yang membagi laba setelah pajak dengan rata - rata modal pada sebuah perusahaan. Rasio ini digunakan untuk melihat tingkat efesiensi perusahaan dalam mengelola ekuitasnya untuk menghasilkan laba bersih perusahaan" (Ikhsan, Alfurkaniati, Safrida, Lubis, Dalimunthe, \& Abdulah, 2016 : 82). Secara teori ROE dirumuskan sebgai berikut : Pengembalian Ekuitas (ROE) $=$ $\frac{\text { Laba Bersih }}{\text { Total Ekuitas }} \times 100 \%$

(Ikhsan, Alfurkaniati, Safrida, Lubis, Dalimunthe, \& Abdulah, 2016, p.82)

6. Earning Per Share (EPS) $\left(\mathrm{X}_{5}\right)$ Menurut Baridwan (2004) earning per share adalah jumlah pendapatan yang diperoleh dalam satu periode untuk tiap lembar saham yang beredar. Sedangkan Larson (2001) mendefinisikan earning per share bisa disebut juga sebagai pendapatan bersih per lembar saham yaitu jumlah pendapatan yang didapat dari tiap-tiap lembar saham biasa yang disetorkan perusahaan. Rumus untuk menghitung rasio ini yaitu:

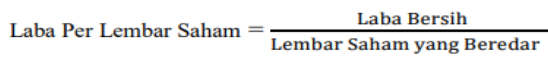




\section{KerangkaKonseptual}

Gambaran singkat dari penelitian ini dapat dilihat di kerangka konseptual dibawah ini :

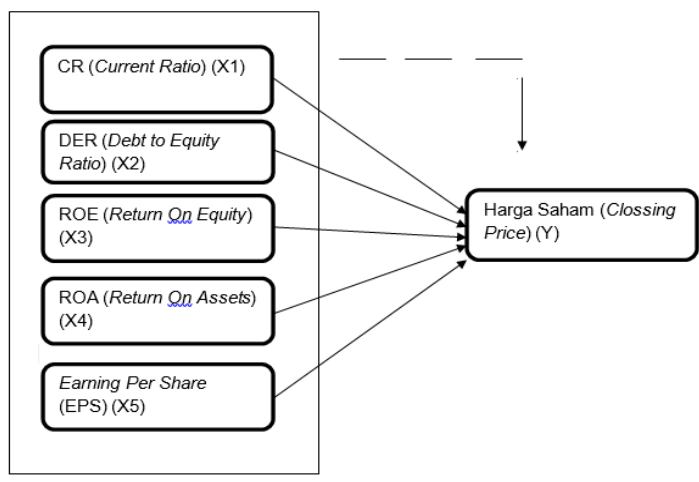

Gambar 1 : Kerangka Konseptual

Sumber : Diolah, 2020

\section{MetodePenelitian}

Jenis penelitian yang digunakan dalam penelitian ini adalah penelitian kuantitatif dengan pendekatan deskriptif. Data kuantitatif pada penelitian ini adalah harga yang berbentuk angka. Penelitian ini menggunakan metode regresi linear berganda untuk menguji hipotesis dengan alat analisis statistik berupa software SPSS Versi 21. Pengujian hipotesis dilakukan setelah model regesi linear berganda yang akan digunakan dianggap layak atau bebas dari pelanggaran asumsi klasik agar hasil pengujian dapat diinterprestasikan dengan tepat. Pengujian asumsi klasik meliputi uji normalitas, uji multikolinieritas, uji autokorelasi, uji heteroskedastisitas

\section{Hasil Penelitian}

\section{Analisis Regresi Linier Berganda}

Alat analisis yang digunakan dalam penelitian ini adalah regresi linier berganda dengan variabel dependen adalah Harga Saham dan variabel independen adalah Current Ratio, Return on equity (ROE), Earning Per Share dan juga Earning Per Share. Model regresi yang digunakan adalah sebagai berikut :

\section{Tabel 1}

\section{Analisis Regresi Linier Berganda}

\begin{tabular}{|c|c|c|c|}
\hline \multirow{2}{*}{\multicolumn{2}{|c|}{ Model }} & \multicolumn{2}{|c|}{$\begin{array}{c}\text { Unstandardized } \\
\text { Coefficients }\end{array}$} \\
\hline & & $\mathrm{B}$ & Std. Error \\
\hline \multirow{6}{*}{1} & (Constant) & .967 & 1.518 \\
\hline & Ln_X1 & -.009 & .112 \\
\hline & Ln_X2 & -.198 & .185 \\
\hline & Ln_X3 & -1.230 & .423 \\
\hline & Ln_X4 & 1.204 & .427 \\
\hline & Ln_X5 & .677 & .093 \\
\hline
\end{tabular}

Sumber : Diolah Penulis 2020

$\mathrm{Y}=0,967+-.009 \mathrm{X}_{1}+-.198 \mathrm{X}_{2}+-1.230 \mathrm{X}_{3}$

$+1.204 \mathrm{X}_{4}+0,677 \mathrm{X}_{5}+\mathrm{e}$

Keterangan:

Dari persamaan tersebut dapat diketahui bahwa :

1. Nilai koefisien regresi variabel Current Ratio -.009 adalah negatif, dengan demikian dapat disimpulkan tidak adanya hubungan searah antara variabel bebas dan variabel terikat. Hal ini berarti bahwa setiap peningkatan Current Ratio sebesar 1 kali maka harga saham akan menurun sebesar .009 dengan asumsi variabel yang lain konstan

2. Nilai koefisien regresi variabel Debt to Equity Ratio -.198 adalah negatif, dengan demikian dapat disimpulkan tidak adanya hubungan searah antara variabel bebas dan variabel terikat. Hal ini berarti bahwa setiap peningkatan Debt to Equity Ratio sebesar 1 kali maka harga saham akan menurun sebesar -.198 dengan asumsi variabel yang lain konstan

3. Nilai koefisien regresi variabel Return On Assets -1.230 adalah negatif, dengan demikian dapat disimpulkan tidak adanya hubungan searah antara variabel bebas dan variabel terikat. Hal ini berarti bahwa setiap peningkatan Return On Assets sebesar 1 kali maka harga saham akan menurun sebesar 1.230 dengan asumsi variabel yang lain konstan 
4. Nilai koefisien regresi variabel Return on equity (ROE) 1.204 adalah positif, dengan demikian dapat disimpulkan adanya hubungan searah antara variabel bebas dan variabel terikat. Hal ini berarti bahwa setiap peningkatan Return on equity (ROE) sebesar 1 kali maka harga saham akan meningkat sebesar 1.204 dengan asumsi variabel yang lain konstan

5. Nilai koefisien regresi variabel Earning Per Share 0,677 adalah positif, dengan demikian dapat disimpulkan adanya hubungan searah antara variabel bebas dan variabel terikat. Hal ini berarti bahwa setiap peningkatan Earning Per Share sebesar 1 kali maka harga saham akan meningkatkan sebesar 0,677 dengan asumsi variabel yang lain konstan

\section{Hasil Uji Hipotesis}

Adapun untuk menguji signifikan tidaknya hipotesis tersebut digunakan uji hipotesis sebagai berikut:

1. Uji F ( Pengujian secara simultan )

\section{Tabel 2}

\begin{tabular}{|ll|c|c|}
\hline \multicolumn{2}{|c|}{ Uji F } \\
\hline \multicolumn{1}{|c|}{$\begin{array}{l}\text { Rodel } \\
1\end{array}$} & $\begin{array}{l}\text { Regression } \\
\text { Residual } \\
\text { Total }\end{array}$ & 13.529 & Sig. \\
\hline
\end{tabular}

Sumber : Diolah Penulis 2020

Berdasarkan hasil uji $\mathrm{F}$ pada Tabel diatas diketahui bahwa nilai Sig. = 0,000 lebih kecil dari 0,05, memiliki nilai $\mathrm{F}$ hitung sebesar 13.529 lebih besar dari $F$ tabel sebesar 2.58 yang artinya semua variabel independen secara simultan (bersama-sama) memiliki pengaruh yang signifikan terhadap variabel dependen, sehingga model regresi dapat digunakan untuk memprediksi variabel dependen secara Bersama-sama berpengaruh terhadap variabel terikat. Dengan kata lain Current Ratio, Debt to Equity Ratio, Return On Assets, Return On Equity dan Earning Per Share berpengaruh secara simultan terhadap harga saham.

2. Uji Determinasi

3. Koefisien Determinasi $\left(\mathrm{R}^{2}\right)$ digunakan untuk mengetahui seberapa jauh kemampuan suatu model penelitian dalam menjelaskan variasi variabel dependen yang ada

Tabel 3

Model Summary

\begin{tabular}{|l|r|r|}
\hline Model & \multicolumn{1}{|c|}{$\mathrm{R}$} & R Square \\
& & \\
\hline 1 & $.796^{\mathrm{a}}$ & .634 \\
\hline
\end{tabular}

Sumber : Data Diolah Penulis 2020

Tabel model summary terlihat nilai Nilai R dengan nilai sebesar 0,796 atau $79,6 \%$ adalah koefisien korelasi yang menunjukkan tingkat hubungan antara variabel Current Ratio, Debt to Equity Ratio, Return On Assets, Return On Equity dan Earning Per Share terhadap harga saham. Nilai korelasi tersebut menunjukkan tingkat hubungan kuat karena berada di antara 0,600 sampai dengan 0,799. Tabel model summary terlihat nilai $\mathrm{R}$ Square nilai sebesar 0,634 atau dengan kata lain 63,4\%, yang artinya model penelitian mampu menjelaskan dari perubahan harga saham. Sedangkan sisanya (100\%$63,4 \%=26,6 \%)$ dijelaskan oleh faktor lain, dimana peneliti tidak melakukan penelitian faktor tersebut

4. Uji t ( Pengujian secara parsial )

\section{Tabel 5}

Uji t

\begin{tabular}{|rl|r|r|}
\hline \multicolumn{1}{|l|}{ Model } & & \multicolumn{1}{c|}{$\mathrm{t}$} & \multicolumn{1}{c|}{ Sig. } \\
\hline \multirow{4}{*}{1} & (Constant) & .637 & .528 \\
& Ln_X1 & -.077 & .939 \\
& Ln_X2 & -1.066 & .293 \\
& Ln_X3 & -2.906 & .006 \\
& & & \\
& & & \\
\end{tabular}

JIEB, Jilid 6, No 3, November 2020 ISSN Online 2615-2134 


\section{\begin{tabular}{|l|l|l|}
\hline Ln_X5 & 7.260 & .000 \\
\hline
\end{tabular}}

Sumber : Diolah Penulis 2020

Berdasarkan hasil uji t yang tercantum pada tabel diatas, maka dapat dilihat bahwa:

a. Nilai Konstanta sebesar 0,967, artinya apabila X1, X2, X3, X4 dan $\mathrm{X} 5$ tidak ada atau nilainya adalah 0 , maka Y nilainya sebesar 0,967

b. $\mathrm{X} 1$ didapatkan nilai sig. $=0,939$ (Nilai Sig. > 0,05) dan memiliki nilai t-hitung sebesar $-0,077$ dan lebih kecil dari nilai t-tabel sebesar 1.67943 artinya secara parsial tidak berpengaruh signifikan terhadap variabel $Y$. Dengan demikian Current Ratio tidak berpengaruh signifikan terhadap Harga Saham Pada Perusahaan Jasa Tranportasi yang Terdaftar di BEI Periode 2015-2019.

c. $\mathrm{X} 2$ didapatkan nilai sig. $=0,293$ (Nilai Sig. > 0,05) dan memiliki nilai t-hitung sebesar -1.066 dan lebih kecil dari nilai t-tabel sebesar 1.67943 artinya secara parsial tidak berpengaruh signifikan terhadap variabel Y. Dengan demikian DER (Debt to Equity Ratio) tidak berpengaruh signifikan terhadap Harga Saham Pada Perusahaan Jasa Tranportasi yang Terdaftar di BEI Periode 2015-2019.

d. X3 didapatkan nilai sig. $=0,006$ (Nilai Sig. < 0,05) dan memiliki nilai t-hitung sebesar -2.906 dan lebih negatif lebih besar dari nilai t-tabel sebesar 1.67943 artinya secara parsial negative berpengaruh signifikan terhadap variabel Y. Dengan demikian ROA (Return On Assets) berpengaruh negatif signifikan terhadap Harga Saham Pada Perusahaan Jasa Tranportasi yang Terdaftar di BEI Periode 20152019. e. X4 didapatkan nilai sig. $=0,007$ (Nilai Sig. < 0,05) dan memiliki nilai t-hitung sebesar 2.821 dan lebih besar dari nilai t-tabel sebesar 1.67943 artinya secara parsial berpengaruh signifikan terhadap variabel $Y$. Dengan demikian juga ROE (Return On Equity) berpengaruh signifikan terhadap Harga Saham Pada Perusahaan Jasa Tranportasi yang Terdaftar di BEI Periode 20152019.

f. X5 didapatkan nilai sig. $=0,000$ (Nilai Sig. < 0,05) dan memiliki nilai t-hitung sebesar -4.118 dan lebih negatif lebih besar dari nilai t-tabel sebesar 1.67943 artinya secara parsial negatif berpengaruh signifikan terhadap variabel $\mathrm{Y}$. Dengan demikian juga Earning Per Share (EPS) negatif berpengaruh signifikan terhadap Harga Saham Pada Perusahaan Jasa Tranportasi yang Terdaftar di BEI Periode 2015-2019.

\section{Uji Dominan}

Tabel 6

Uji Dominan

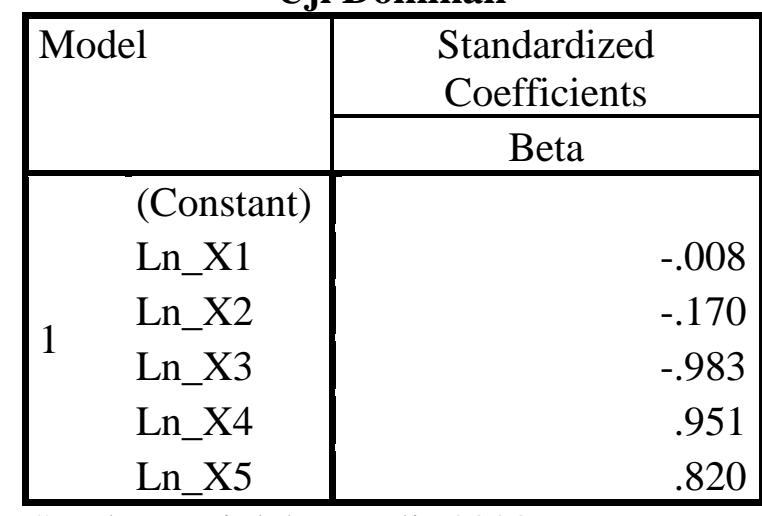

Sumber : Diolah Penulis 2020

Variabel Current Ratio memiliki nilai sebesar -.008, Debt to Equity Ratio memiliki nilai sebesar -.170, Return On Assets memiliki nilai sebesar -.983,

JIEB, Jilid 6, No 3, November 2020 ISSN Online 2615-2134 
Return On Equity memiliki nilai sebesar .951 dan Earning Per Share memiliki nilai sebesar .820. Dengan demikian variabel yang berpengaruh dominan Terhadap Harga Saham Pada Perusahaan Jasa Tranportasi yang Terdaftar di BEI Periode 2015-2019 adalah variabel Return On Equity

\section{Pembahasan}

Pengaruh Current Ratio, Debt To Equity Ratio, Return On Assets, Return On Equity, Dan Earning Per Share Secara Simultan Terhadap Harga Saham

Berdasarkan hasil uji $\mathrm{F}$ pada Tabel diatas diketahui bahwa nilai Sig. $=0,000$ lebih kecil dari 0,05 yang artinya semua variabel independen secara simultan (bersama-sama) memiliki pengaruh yang signifikan terhadap variabel dependen, sehingga model regresi dapat digunakan untuk memprediksi variabel dependen secara Bersama-sama berpengaruh terhadap variabel terikat. Dengan kata lain Current Ratio, Debt to Equity Ratio, Return On Assets, Return On Equity, dan Earning Per Share berpengaruh secara simultan terhadap harga saham Perusahaan Jasa Tranportasi yang Terdaftar di BEI Periode 2015-2019.

Berdasarkan Nilai $\mathrm{R}$ dengan nilai sebesar 0,796 atau $79,6 \%$ adalah koefisien korelasi yang menunjukkan tingkat hubungan antara variabel Current Ratio, Debt to Equity Ratio, Return On Assets, Return On Equity dan Earning Per Share terhadap harga saham. Nilai korelasi tersebut menunjukkan tingkat hubungan kuat karena berada di antara 0,600 sampai dengan 0,799. Tabel model summary terlihat nilai $\mathrm{R}$ Square nilai sebesar 0,634 atau dengan kata lain $63,4 \%$, yang artinya model penelitian mampu menjelaskan dari perubahan harga saham. Sedangkan sisanya $(100 \%-63,4 \%=26,6 \%)$ dijelaskan oleh faktor lain, dimana peneliti tidak melakukan penelitian faktor tersebut. Hal ini disebabkan karena Perusahaan Jasa Tranportasi yang Terdaftar di BEI Periode
2015-2019 yakin dan telah mampu dalam mengelola kegiatan usahanya yang terlihat dari jumlah aset, jumlah laba, dan jumlah usaha yang diberikan

Pengaruh Current Ratio, Debt To Equity Ratio, Return On Assets, Return On Equity Dan Earning Per Share Secara Parsial Terhadap Harga Saham

1. Pengaruh Current Ratio Secara Parsial Terhadap Harga Saham

Berdasarkan hasil pengujian didapatkan nilai sig. 0,939 (Nilai Sig. > $0,05)$ dan memiliki nilai t-hitung sebesar -0,077 dan lebih kecil dari nilai t-tabel sebesar 1.67943 artinya secara parsial tidak berpengaruh signifikan terhadap variabel Y. Dengan demikian Current Ratio tidak berpengaruh signifikan terhadap Harga Saham Pada Perusahaan Jasa Tranportasi yang Terdaftar di BEI Periode 2015-2019.

Artinya besar kecilnya nilai Current Ratio dalam perusahaan tersebut belum dapat mempengaruhi tinggi rendahnya harga saham. Kondisi ini menggambarkan sejauh mana kemampuan perusahaan dalam memenuhi kewajiban jangka pendek Perusahaan Jasa Tranportasi yang Terdaftar di BEI Periode 2015-2019 masih belum berjalan dengan baik

2. Pengaruh Debt To Equity Ratio Secara Parsial Terhadap Harga Saham

Berdasarkan hasil pengujian didapatkan nilai sig. 0,293 (Nilai Sig. $>0,05)$ dan memiliki nilai t-hitung sebesar -1.066 dan lebih kecil dari nilai t-tabel sebesar 1.67943 artinya secara parsial tidak berpengaruh signifikan terhadap variabel Y. Dengan demikian DER (Debt to Equity Ratio) tidak berpengaruh signifikan terhadap Harga Saham Pada Perusahaan Jasa Tranportasi yang Terdaftar di BEI Periode 2015-2019.

Artinya besar kecilnya nilai DER (Debt to Equity Ratio) dalam perusahaan tersebut belum dapat 
mempengaruhi tinggi rendahnya harga saham. Kondisi ini menggambarkan sejauh mana penggunaan untuk menilai utang Perusahaan Jasa Tranportasi yang Terdaftar di BEI Periode 20152019 masih belum berjalan dengan baik

Tidak berpengaruhnya DER terhadap harga saham Pada Perusahaan Jasa Tranportasi yang Terdaftar di BEI Periode 2015-2019 mengindikasikan bahwa sebagian besar investor menginginkan laba jangka pendek berupa capital gain sehingga dalam mempertimbangkan pembelian saham tidak mempertimbangkan DER perusahaan, akan tetapi mengikuti trend yang terjadi di pasar. Ini dikarenakan kebanyakan orientasi investor adalah capital gain oriented bukan dividend oriented.

Hasil penelitian ini juga menunjukkan bahwa informasi perubahan DER yang sebagaimana bisa diperoleh dari laporan keuangan tidak berpengaruh pada keputusan atas harga saham Pada Perusahaan Jasa Tranportasi yang Terdaftar di BEI Periode 2015-2019. Hal ini mungkin terjadi karena investor dalam melakukan investasi tidak memandang penting penggunaan hutang maupun pengembalian bunga dan pokok hutang yang pada akhirnya tidak mempengaruhi persepsi investor terhadap keuntungan di masa yang akan datang.

Hal ini berarti DER bukan merupakan pertimbangan utama bagi investor ketika akan membeli saham. DER tidak menjadi atau sebagai pertimbangan investor dalam menentukan investasinya di Perusahaan Jasa Tranportasi yang Terdaftar di BEI Periode 2015-2019

3. Pengaruh Return On Assets Secara Parsial Terhadap Harga Saham

Berdasarkan hasil pengujian didapatkan 0,006 (Nilai Sig. < 0,05) dan memiliki nilai t-hitung sebesar 2.906 dan lebih negatif lebih besar dari nilai t-tabel sebesar 1.67943 artinya secara parsial berpengaruh signifikan terhadap variabel Y. Dengan demikian ROA (Return On Assets) berpengaruh negatif signifikan terhadap Harga Saham Pada Perusahaan Jasa Tranportasi yang Terdaftar di BEI Periode 2015-2019.

Artinya besar kecilnya nilai ROA (Return On Assets) dalam perusahaan tersebut belum dapat mempengaruhi tinggi rendahnya harga saham. Kondisi ini menggambarkan sejauh mana penggunaan tingkat efesiensi perusahaan dalam mengelola ekuitasnya untuk menghasilkan laba bersih perusahaan Perusahaan Jasa Tranportasi yang Terdaftar di BEI Periode 2015-2019 masih belum berjalan dengan baik

4. Pengaruh Return On Equity Secara Parsial Terhadap Harga Saham

Berdasarkan hasil pengujian didapatkan nilai sig. 0,007 (Nilai Sig. < $0,05)$ dan memiliki nilai t-hitung sebesar 2.821 dan lebih besar dari nilai t-tabel sebesar 1.67943 artinya secara parsial berpengaruh signifikan terhadap variabel Y. Dengan demikian juga ROE (Return On Equity) berpengaruh signifikan terhadap Harga Saham Pada Perusahaan Jasa Tranportasi yang Terdaftar di BEI Periode 2015-2019

Artinya besar kecilnya nilai ROE (Return On Equity) dalam perusahaan tersebut belum dapat mempengaruhi tinggi rendahnya harga saham. Kondisi ini menggambarkan sejauh mana penggunaan rasio yang membagi laba setelah pajak dengan rata - rata modal pada sebuah Perusahaan Jasa Tranportasi yang Terdaftar di BEI Periode 2015-2019 masih belum berjalan dengan baik.

Hal ini mengindikasikan bahwa seberapa besar kenaikan maupun 
penurunan ROE mempengaruhi fluktuasi harga saham. Hal ini dapat dijelaskan bahwa besar kecilnya ROE dalam suatu perusahaan memiliki dampak yang begitu besar terhadap kesehjateraan stakeholder dalam perusahaan tersebut terutama bagi para investor. Jika ROE perusahaan semakin meningkat, maka investor akan semakin tertarik untuk berinvestasi pada perusahaan tersebut dan hal ini akan berdampak positif pada kenaikan harga saham perusahaan

5. Pengaruh Earning Per Share Secara Parsial Terhadap Harga Saham

Berdasarkan hasil pengujian didapatkan nilai sig. 0,000 (Nilai Sig. < 0,05) dan memiliki nilai t-hitung sebesar -4.118 dan lebih negatif lebih besar dari nilai t-tabel sebesar 1.67943 artinya secara parsial negatif berpengaruh signifikan terhadap variabel Y. Dengan demikian juga Earning Per Share (EPS) negatif berpengaruh signifikan terhadap Harga Saham Pada Perusahaan Jasa Tranportasi yang Terdaftar di BEI Periode 2015-2019.

Artinya besar kecilnya nilai Earning Per Share (EPS) dalam perusahaan tersebut dapat mempengaruhi tinggi rendahnya harga saham. Kondisi ini menggambarkan sejauh mana rasio ini menunjukkan besarnya laba bersih perusahaan yang siap dibagikan untuk semua pemegang saham Perusahaan Jasa Tranportasi yang Terdaftar di BEI Periode 20152019 berjalan dengan baik.

Artinya jika Earning Per Share semakin besar maka akan bedampak pada harga saham naik. Dan sebaliknya jika Earning Per Share mengalami perubahan turun maka harga saham cenderung turun

Dengan demikian EPS yang besar maka membuat investor tertarik untuk membeli saham Perusahaan Jasa Tranportasi yang Terdaftar di BEI
Periode 2015-2019, karena akan mendapatkan penerimaan yang besar dari tiap lembar sahamnya. Oleh karena itu, investor dapat menilai potensi pendapatan yang akan diterimanya melalui Earning Per Share (EPS) suatu perusahaan.

Laba per lembar saham (Earning Per Share) merupakan salah satu variabel penting yang dianalisis oleh para investor sebelum mereka melakukan investasi di Perusahaan Jasa Tranportasi yang Terdaftar di BEI Periode 2015-2019. Persepsi investor terhadap laba per lembar saham (Earning Per Share) sangat krusial pada Perusahaan Jasa Tranportasi yang Terdaftar di BEI Periode 2015-2019, karena investor yang ingin melakukan investasi saham tentu saja dengan harapan dapat memperoleh return yang sebesar- besarnya

Variabel Yang Berpengaruh Dominan Terhadap Harga Saham

Variabel Current Ratio memiliki nilai sebesar -.008, Debt to Equity Ratio memiliki nilai sebesar -.170, Return On Assets memiliki nilai sebesar -.983, Return On Equity memiliki nilai sebesar .951 dan Earning Per Share memiliki nilai sebesar .820. Dengan demikian variabel yang berpengaruh dominan Terhadap Harga Saham Pada Perusahaan Jasa Tranportasi yang Terdaftar di BEI Periode 2015-2019 adalah variabel Return On Equity. Jika Return On Equity perusahaan semakin meningkat, maka investor akan semakin tertarik untuk berinvestasi pada perusahaan tersebut dan hal ini akan berdampak positif pada kenaikan harga saham perusahaan

\section{Kesimpulan}

Current Ratio, Debt to Equity Ratio, Return On Assets, Return On Equity, dan Earning Per Share berpengaruh secara simultan terhadap harga saham Perusahaan Jasa Tranportasi yang Terdaftar di BEI Periode 2015-2019. Current Ratio tidak berpengaruh signifikan terhadap Harga Saham Pada Perusahaan Jasa Tranportasi 
yang Terdaftar di BEI Periode 2015-2019. Artinya besar kecilnya nilai Current Ratio dalam perusahaan tersebut belum dapat mempengaruhi tinggi rendahnya harga saham. DER (Debt to Equity Ratio) tidak berpengaruh signifikan terhadap Harga Saham Pada Perusahaan Jasa Tranportasi yang Terdaftar di BEI Periode 2015-2019. Artinya besar kecilnya nilai DER (Debt to Equity Ratio) dalam perusahaan tersebut belum dapat mempengaruhi tinggi rendahnya harga saham. ROA (Return On Assets) berpengaruh signifikan terhadap Harga Saham Pada Perusahaan Jasa Tranportasi yang Terdaftar di BEI Periode 2015-2019. Artinya besar kecilnya nilai ROA (Return On Assets) dalam perusahaan tersebut dapat mempengaruhi tinggi rendahnya harga saham. ROE (Return On Equity) berpengaruh signifikan terhadap Harga Saham Pada Perusahaan Jasa Tranportasi yang Terdaftar di BEI Periode 2015-2019. Artinya besar kecilnya nilai ROE (Return On Equity) dalam perusahaan tersebut dapat mempengaruhi tinggi rendahnya harga saham. Earning Per Share (EPS) berpengaruh signifikan terhadap Harga Saham Pada Perusahaan Jasa Tranportasi yang Terdaftar di BEI Periode 2015-2019. Artinya besar kecilnya nilai Earning Per Share (EPS) dalam perusahaan tersebut dapat mempengaruhi tinggi rendahnya harga saham. Variabel yang berpengaruh dominan Terhadap Harga Saham Pada Perusahaan Jasa Tranportasi yang Terdaftar di BEI Periode 2015-2019 adalah variabel Return On Equity.

\section{Saran}

1. Bagi perusahaan

Manajemen perlu memperhatikan kualitas laporan keuangan maupun meningkatkan kinerja keuangannya khususnya Earning Per Share agar dapat membantu investor untuk lebih mengetahui, sehingga para investor tertarik untuk melakukan investasi di Perusahaan penelitian

2. Bagi investor
Bagi investor yang akan membeli saham sebaiknya mempertimbangkan terlebih dahulu mengenai informasiinformasi perusahaan, selain itu melihat kembali laporan keuangan perusahaan dari tahun ke tahun yang telah di publikasikan oleh perusahaan melalui Bursa Efek Indonesia (BEI) untuk dijadikan bahan dasar pertimbangan sebelum melakukan pembelian saham atau berinvestasi. Kemudian lebih memperhatikan Earning Per Share

3. Bagi peneliti selanjutnya

a. Sampel penelitian seharusnya tidak hanya pada Perusahaan Jasa Tranportasi yang Terdaftar di BEI Periode 2015-2019

b. Penelitian berikutnya diharapkan menambah variable-variabel lain baik variabel fundamental internal perusahaan berupa rasio-rasio keuangan maupun variabel fundamental eksternal perusahaan seperti perubahan, kurs valuta asing, dan inflasi yang dapat mempengaruhi harga saham.

c. Bagi peneliti selanjutnya diharapkan dapat menambah tahun pengamatan, mengingat penelitian ini hanya melakukan pengamatan selama 5 tahun

\section{DAFTAR PUSTAKA}

Aang, Ross. (1997). Buku Pintar Pasar Modal Indonesia. Edisi Pertama. Jakarta: Mediasoft Indonesia.

Arifin, Ali. (2007). Membaca Saham. Yogyakarta: Penerbit Andi.

Andi Aspar Ramadhana (2018), Pengaruh Kinerja Keuangan Terhadap Harga Saham.

https://www.researchgate.net/publi cation/327871411_PENGARUH_K INERJA_KEUANGAN_TERHAD AP_HARGA_SAHAM (Diakses 12 April 2020) 
Antareka, Lena. (2016). Pengaruh Current Ratio (CR), Retrn On Assests (ROA), Earning Per Share (EPS), dan Net Profit Margin (NPM) Terhadap Harga Saham Perusahaan Real Estate and Property yang Terdaftar di Bursa Efek Indonesia periode 2010-2014. Fakultas Ekonomi dan Bisnis Universitas Muhamadiyah Surakarta. http://eprints.ums.ac.id/44998/1/N ASKAH\%20PUBLIKASI.pdf (Diakses 12 April 2020)

Bringham \& Houston. (2012). Dasar-Dasar Manajemen Keuangan. Jakarta: Salemba Empat.

Bringham \& Housto. (2010). Dasar-Dasar Manajemen Keuangan. Edisi 11. Jakarta: Salemba Empat.

Eduardus, Tandelilin. (2001). Analisis Investasi dan Manajemen Portofolio. Edisi Pertama. Yogyakarta: BPFE-Yogyakarta.

Egam, Gerald Edsel Yermia. (2017). Pengaruh Return On Assets, Return On Equity, Net Profit Margin dan Earing Per Share Terhadap Harga Saham Perusahaan Yang Tergabung Dalam Indeks LQ45 Di Bursa Efek Indonesia tahun 2013-2015. Jurnal EMBA, Vol.5 No.1 Maret 2017, Hal. 105-114.

https://ejournal.unsrat.ac.id/index.p hp/emba/article/view/15455

(Diakses 12 April 2020)

Fahlevi, Rido Raiza. (2018). Pengaruh Kinerja Keuangan Terhadap Harga Saham Pada Perusahaan Perbankan yang Terdaftar Di Bursa Efek Indonesia. Akuntabel 15 (1), 2018 39-48.

Febriyani, Rika Marta. (2016). Pengaruh Return On Assets, Debt to Equity Ratio dan Deviden Payout Ratio Terhadap Harga Saham. Universitas PGRI Yogyakarta. http://repository.upy.ac.id/1338/1/A rtikel.pdf (Diakses 12 April 2020)
Ghozali, I. (2011). Aplikasi Analisis Multivariate Dengan Program SPSS (4 ed.). Semarang: Badan Penerbit Universitas Diponegoro.

Husnan, Suad. (1998). Dasar - Dasar Teori Portofolio \& Analisis Sekuritas. Yogyakarta: UPP AMP YKPN

(2008). Manajemen

Keuangan : Teori dan Penerapan Buku 1. Edisi Kelima. Yogyakarta: BPFE.

Ikatan Alumni Indonesia. (2012). Manajemen Keuangan. Yogyakarta: EKONOSIA.

Ikhsan, A., Alfurkaniati, Safrida, L., Dalimunthe, Muhammad I.,\& Abdullah, I. 2016. Analisis Laporan Keuangan.Cetakan Pertama. Medan: Madenatera.

Ikhsan, A., Muhyarsyah, Tanjung, H., \& Oktaviani, A. (2014). Metodologi Penelitian Bisnis Untuk Akuntansi Dan Manajemen. Bandung: Citapustaka Media.

Jogiyanto. (2010). Analisis dan Desain Sistem Informasi. Edisi IV. Yogyakarta: Penerbit Andi.

Kasmir. (2012).Analisis Laporan Keuangan. Edisi Revisi. Jakarta: PT Raja Grafindo Perkasa.

Lestari, Ninda Tri. (2018). Analisis Pengaruh Kinerja Keuangan Terhadap Harga Saham Pada Perusahaan Pertanian yang Terdaftar di BEI. Fakultas Ekonomi dan Bisnis Universitas Muhammadiyah Surakarta. http://eprints.ums.ac.id/60336/1/N ASKAH\%20PUBLIKASI.pdf (Diakses 12 April 2020)

Lely Ria Nuraini, 2017, Pengaruh Kinerja Keuangan Terhadap Harga Saham Perusahaan Jasa (Sub.Transportasi) Yang Tercatat Di BEI. http://eprints.perbanas.ac.id/2948/1/ ARTIKEL\%20ILMIAH.pdf (Diakses 12 April 2020) 
Munawir S. (2010). Analsis Laporan Keuangan. Yogyakarta: Penerbit Liberty.

Ninda Tri Lestari (2018), Analisis Pengaruh Kinerja Keuangan Terhadap Harga Saham pad Perusahaan pertanian yang Terdaftar di BEI. http://eprints.ums.ac.id/60336/

(Diakses 12 April 2020)

Novitasari, Riris (2012). Pengaruh Current Ratio (CR), Debt To Equity Ratio (DER), Return On Assets (ROA) Dan Return On Equity (ROE) Terhadap Harga Saham (Studi Pada Perusahaan Sub Sektor Telekomunikasi Yang Terdaftar Di Bursa Efek Indonesia Periode 20132016). Administrasi Bisnis, Universitas Diponegoro, Indonesia. https://ejournal3.undip.ac.id/index. php/jiab/article/view/17840 (Diakses 12 April 2020)

Puspitasari, CS. (2014). Pengaruh Kinerja Keuangan Tehadap Harga Saham Perusahaan Yang Tergolong Ke Dalam Indeks LQ 45 Yand Terdaftar Di Bursa Efek Indonesia. Skripsi, 1-77. https://repository.widyatama.ac.id/x mlui/handle/123456789/4493

(Diakses 12 April 2020)

Ramadhana, Andi Aspar. (2018). Pengaruh Kinerja Keuangan Terhadap Harga Saham. Jurnal Organisasi dan Manajemen, Halaman 47-64.

Ramadhana, Recly Bima. (2016). Analsis Rasio Untuk Menilai Kinerja Keuangan Pada PT. H.M. SAMPOERNA Tbk. Jurnal Ilmu dan Riset Manajemen, 5, 1-18. https://www.academia.edu/352724 41/ANALISIS_RASIO_KEUANG AN_UNTUK_MENILAIN_KINE RJA_KEUANGAN_PADA_PT._H .M_SAMPOERNA_Tbk (Diakses 12 April 2020)

Rido Raiza Fahlevi (2018), Pengaruh Kinerja Keuangan Terhadap Harga
Saham pada Perusahaan Perbankan yang Terdaftar di Bursa Efek Indonesia.

https://www.researchgate.net/publi cation/332967999_PENGARUH_K INERJA_KEUANGAN_TERHAD AP_HARGA_SAHAM_PADA_PE RUSAHAAN_PERBANKAN_YA NG_TERDAFTAR_DI_BURSA_E FEK_INDONESIA (Diakses 12 April 2020)

Singgih, Santoso \& Tjiptono. (2001). Riset Pemasaran Konsep dan Aplikasi dengan SPSS. Jakarta: Elex Media Komputindo.

Sugiyono. (2010). Metode Penelitian Kuantitatif Kualitatif dan $R \& D$. Bandung: CV Alfabeta.

Sunariyah. (2006). Pengantar Pengetahuan Pasar Modal. Yogyakarta: UPP STIM YKPN.

Tyastari, Tifani Titah Dwi. (2015). Pengaruh Kinerja Akuntansi dan Kinerja Keuangan Terhadap Harga Saham (Sudi pada Perusahaan Sektor Keuangan yang Listing di Bursa Efek Indonesia). Fakultas Ekonomi dan Bisnis Universitas Brawijaya. https://jimfeb.ub.ac.id/index.php/ji mfeb/article/view/942 (Diakses 12 April 2020)

Usman, Marzuki. (1994). ABC Pasar Modal Indonesia. Jakarta: LPPI/IBI.

Zurliarni, Sri. (2012). Pengaruh Kinerja Keuangan Terhadap Harga Saham Pada Perusahaan Mining dan Mining Service di Bursa Efek Indonesia (BEI). Jurnal Aplikasi Bisnis. Vol. 3 No. 1, Oktober 2012. http://administrasibisnis.studentjour nal.ub.ac.id/index.php/jab/article/vi ewFile/2647/3040 (Diakses 12 April 2020)

www.finance.yahoo.com

www.idx.co.id

www.sahamok.com

JIEB, Jilid 6, No 3, November 2020 ISSN Online 2615-2134 